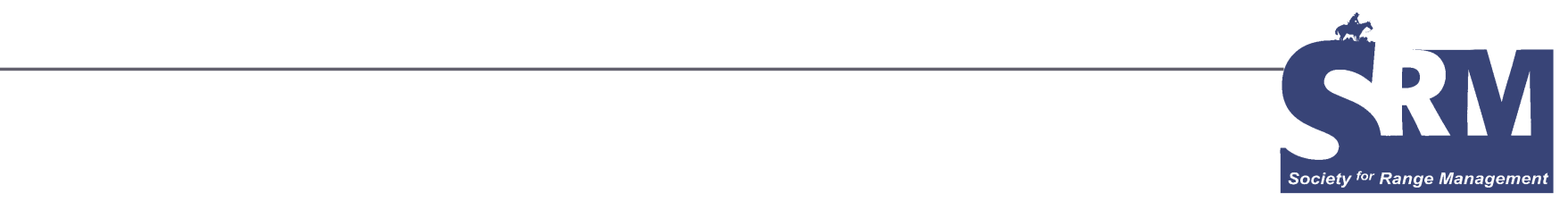

\title{
Ranchers as a Keystone Species in a West That Works
}

\section{By Richard L. Knight}

Editor's Note: This paper is a portion of the presentation by Dr Knight at the Plenary Session, Society for Range Management, Reno, Nevada, February 12, 2007.

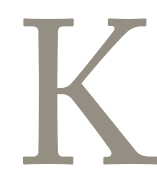

eystone species - a species whose importance is disproportionate to its numbers.

Ranchers and ranching are both an occupation American West. As the landscape of the West is blended, half public and half private, ranching builds connections between public and private lands, and between rural and urban communities. Ranching works well, ecologically, economically, and culturally. If ranching declines rather than prospers, so too will the health of human and natural communities decline.

Ecologically, ranching as a land use is compatible with the natural heritage of the West. It keeps lands open and stewarded, keeps human densities low, and safeguards private lands from fragmentation. Economically, ranching provides home-grown food, pays its own way, and supports a fiscally responsible economy. Culturally, ranching covers a time frame dating back over 400 years, one of the oldest land uses that Euro-Americans have given the New World.

A natural alliance exists between urban consumers of food and open space, and rural producers of food and open space. Regretfully, this logical symbiosis has waned during past decades. A strong rural-urban partnership is as essential to a healthy West as is a strong public-private land connection. As these relationships deepen, so too will the health of the human and natural communities of this region. ${ }^{1}$

A honest appraisal about ranching as a land use in the New West, however, first requires that we acknowledge the current "highest and best uses" of the West, both private and public. Exurban development and outdoor recreation are presently the highest and best uses of the private and public lands, respectively, in today's West..$^{2,3}$ These land uses have replaced livestock grazing as the principle use of the West only decades earlier, particularly in the arid West. ${ }^{4,5}$

Because land health is dependent upon land use, it is impossible to discuss ranching without also discussing the land uses that are replacing it. Some people might think it is a far stretch to connect livestock grazing on private and public lands with exurban development and outdoor recreation on private and public lands, but I see it differently. The protection of open space, food production, ecosystem services, and the aesthetics of rural areas runs right through agriculture. At one end stands a rancher, at the other end a developer. We have arrived at a point in our history where conversations about western lands and land health, grazing, ranchettes, and recreation are entwined and cannot be separated. They must be dealt with simultaneously when discussing the future of our Next West. Importantly, these discussions need to include more than just the ecology of competing land uses; they also need to address the economics and the cultural aspects of these land uses as well. ${ }^{6}$

\section{Ecology}

Although land ownership in the West is blended, the division is not equal. The private lands are the best-watered, occur at the lower elevations, and contain the richest soils. ${ }^{7,8}$ Understanding the history of settlement of the public domain is key to appreciating why the federal lands are largely "rock and ice" or "desert and thorn." The implications to biodiversity of this historical truth are even more 
important. The private lands are disproportionately important to the maintenance of our region's natural heritage because they are disproportionately more productive. Although no one has calculated the ratio, private lands may be an order of magnitude more important to the maintenance of the region's biodiversity than are the public lands. Truthfully, however, species of conservation concern could no more survive on just the private lands of the West than they could survive on just the public lands.

Ranching, because it encompasses large amounts of land with low human densities, and because it alters native vegetation in modest ways, has been found to support biodiversity that is of conservation concern. The alternative uses of private and public lands do not tread so lightly. Outdoor recreation is the second leading cause for the decline of Federally threatened and endangered species on public lands, and residential development is the second leading cause for the listing of these species on all lands in the United States, both private and public., ${ }^{9,10}$

Whereas ranching is synonymous with minimal human visitation and structures, both exurban development and outdoor recreation are year-round activities of elevated human densities that both perforate and internally dissect land with roads, trails, house sites, and recreational facilities (camp sties, picnic areas, viewing areas). ${ }^{11}$

When rural lands, whether in farms or ranches, are subdivided, there follows an increase in landscape-level fragmentation. For example, when ranches in Larimer County, Colorado were subdivided, there was an almost ten-fold increase in road densities and fragmentation from houses that perforated the previously intact rangelands. ${ }^{12}$ This observation led us to wonder how biodiversity, from songbirds to carnivores to plants, differed across the principle land uses of today's West. Accordingly, we examined these taxa on a landscape that was part ranchland, part exurban development, and part protected area without livestock. ${ }^{13}$

We found that the ranchlands and protected areas supported birds and carnivores of conservation concern, while the exurban developments supported pretty much the same songbird and carnivore community one found in suburban areas in town (Figs. 1-3). The plant story was a little different. Both the protected areas and the exurban developments were far more weedy than the ranchlands (Fig. 4). ${ }^{14}$ Stewardship, the judicious use of herbicides and livestock, and a discerning eye were the differences here. Ranchers apparently are doing what Aldo Leopold suggested when he wrote, "The central thesis of game management is this: game can be restored by the creative use of the same tools which have heretofore destroyed it-axe, plow, cow, fire, and gun." 15

Critical to understanding the edge affect associated with fragmentation by ranchettes is the awareness that species composition changes as a result of the homes. Human-adapted species, such as brown-headed cowbirds, black-billed magpies, and American robins, all occurred at higher densities near homes and at lower densities away from homes. These species can affect the fitness of birds of
Black-billed Magpie

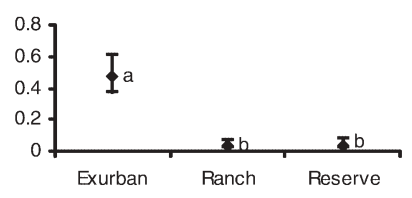

Brewer's Blackbird

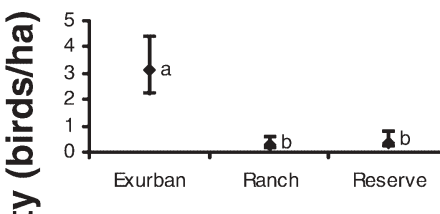

House Wren

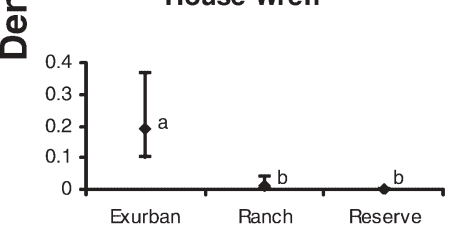

Bullock's Oriole

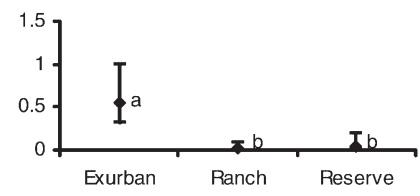

\section{Land use}

Figure 1. Densities and $90 \%$ log-based confidence intervals of bird species that reached their greatest densities on land used for exurban development. Different letters next to density estimates indicate a statistically significant difference at the 0.10 level.

conservation concern through nest parasitism, nest predation, and competition for nesting sites, respectively.

When ranches support viable populations of species sensitive to the harmful effects of sprawl, they serve much the same role as protected areas because they act as "sources" (areas where birth rates of species exceed death rates) of sensitive plant and animal species. If ranchettes serve as "sinks" (places where death rates exceed birth rates) for species of conservation value, populations on these areas are kept afloat by the addition of surplus individuals dispersing from nearby protected areas and ranchlands. ${ }^{16}$

The upshot of the biological changes associated with the conversion of ranchlands to ranchettes will be an altered natural heritage. ${ }^{17}$ In the years to come, as the West gradually transforms itself from rural ranches with low human densities to increasingly sprawl-riddled landscapes with more people, more dogs and cats, more cars and fences, more night lights perforating the once-black night sky, the rich natural diversity that once characterized the rural West will be altered forever. We will have more generalist species-species that thrive in association with humansand fewer specialist species-those whose evolutionary 

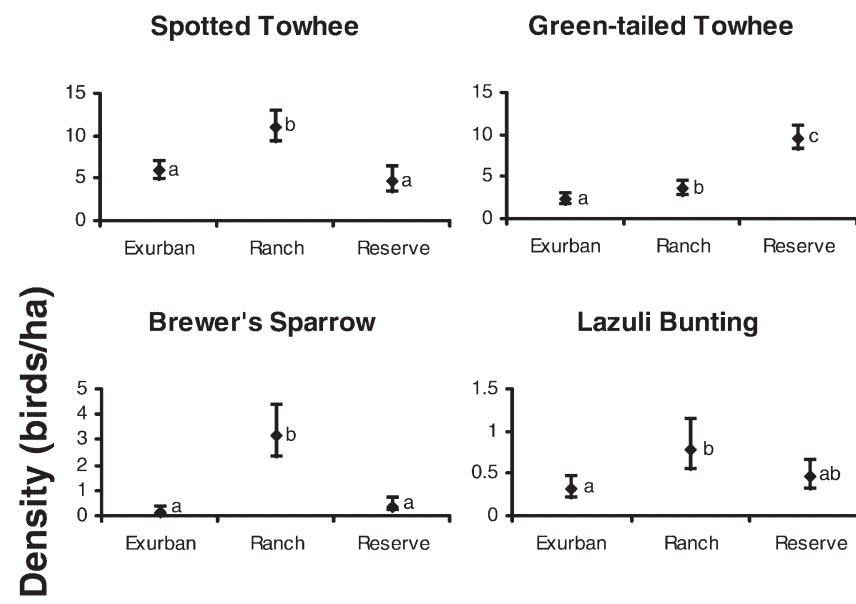

Vesper Sparrow
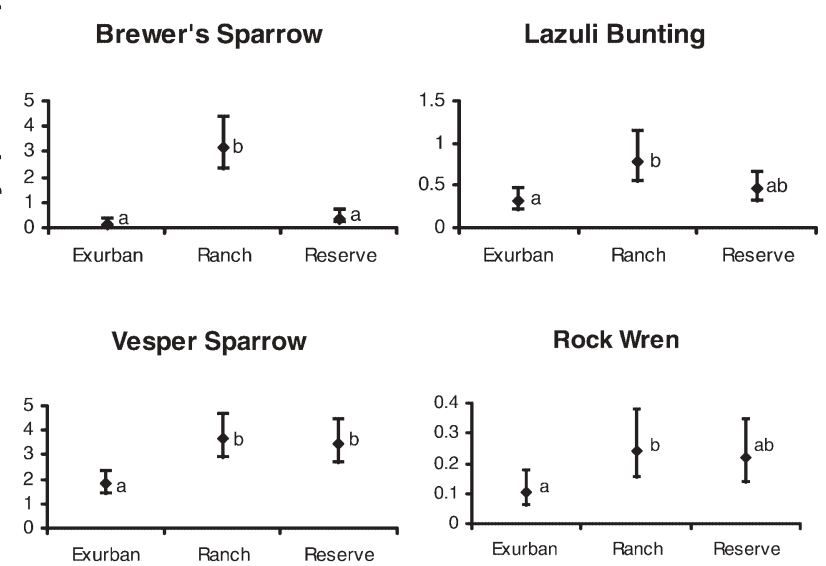

Rock Wren

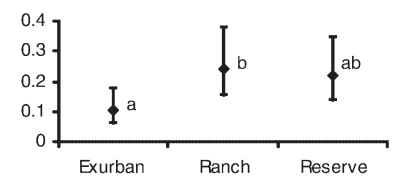

\section{Land use}

Figure 2. Densities plus $90 \%$ log-based confidence intervals of bird species that reached their greatest densities of land used for ranching or reserves. Different letters next to density estimates indicate a statistically significant difference at the 0.10 level.

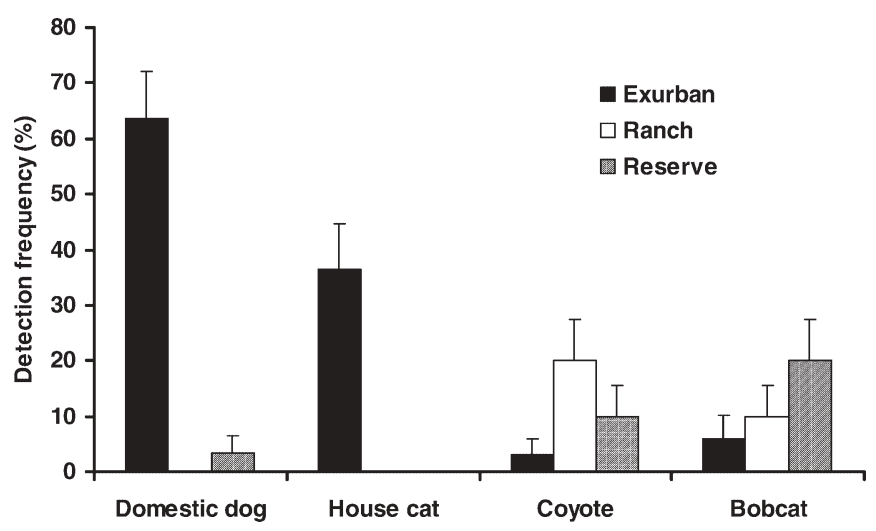

Figure 3. Frequencies ( \pm SE) of carnivore detections at scent stations surveyed on exurban developments, ranches, and reserves.

histories failed to prepare them for elevated human densities and our advanced technology. Rather than lark buntings and bobcats, we will have starlings and striped skunks. Rather than rattlesnakes and warblers, we will have garter snakes and robins. Is that the West we want? It will be the West we get if we do not slow down and get to know the human and natural histories of our region better, and then act to conserve them.

Livestock grazing on public lands is believed by some to threaten biodiversity..$^{18}$ But is it? One of the most thorough analyses on the ecological effects of grazing on public lands compared 26 long-term grazing exclosures with similar

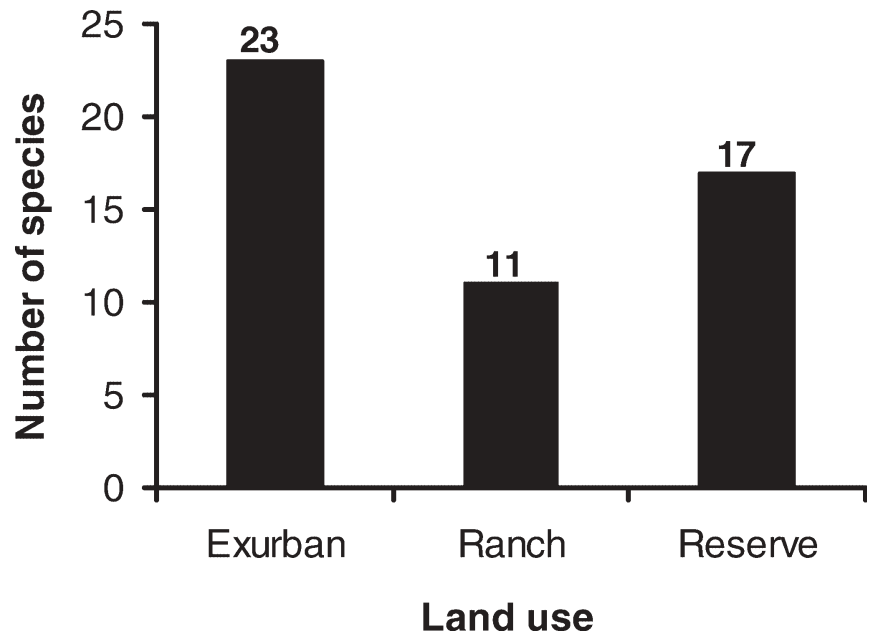

Figure 4. Cumulative number of nonnative plant species by land use. The same number of microplots $(n=276)$ were sampled on exurban developments, ranches, and reserves.

ungrazed areas on national forests in Colorado, Wyoming, Montana, and South Dakota. ${ }^{19}$ The exclosures averaged over 30 years without livestock (once more proving the benefit of having national parks, refuges, and other protected areas across the Western mosaic of landscapes).

The scientists found no differences between the grazed and ungrazed areas in a number of factors: plant species diversity; cover by grasses, forbs, and shrubs; soil texture; and the percentage of nitrogen and carbon in the soil. The authors concluded that:

1) grazing probably has little effect on native species
richness at landscape scales; 2) grazing probably has
little effect on the accelerated spread of most exotic plant
species at landscape scales; 3) grazing affects local plant
species and life-form composition and cover, but spatial
variation is considerable; 4) soil characteristics, climate,
and disturbances may have a greater effect on plant species
diversity than do current levels of grazing; and 5) few
plant species show consistent, directional responses to
grazing or cessation of grazing.

A word of caution regarding all of these findings. The West is not one place, but many places that grade into each other. They have different biological histories, and different ecological structures and functions, upon which cultural histories and landscape have been and are being superimposed. These regional and local differences in the ecology of the West have implications for grazing by domestic ungulates. Slope matters, as does elevation and aspect, and local rainfall. On a longer view, so does the post-Pleistocene environment in the presence of large, social ungulates: bison, elk, pronghorn. At a first approximation, then, some places should be more compatible with grazing by large, social, domestic ungulates than others. 
Grass and shrubs co-evolved with herbivores, species that grazed and browsed their new growth. The West has always been defined by large populations of herbivores, although the actual identity has changed over time. Whether it was mastodons and sloths, or bison and pronghorn, or grasshoppers and rodents, grass and shrubs need the stimulating disturbance brought about by large, blunt-ended incisors clipping their aboveground biomass, not to mention the dung and urine incorporated by hoof action facilitating more efficient nutrient cycling. Today the mastodons are gone and there are fewer bison and pronghorn than what had once occurred. And there are cattle, though not as many as we saw in the last century. But, we have learned that grazing by livestock, when appropriately done, contributes to the necessary disturbance that rangelands require. Perhaps we have come to the point where we measure land health premised on disturbance rather than just rest and realize there is no "balance of nature," but instead a "flux of nature." Getting the disturbance patterns right is the challenge. ${ }^{20}$

Nor are ranchers all one type. Ranching, done right, can coexist with healthy land or even restore land back to health. Done wrong, it can damage and destroy.

\section{Economics}

During a time when America's red ink is swelling large enough to swamp the world's largest economy, it is encouraging to realize that ranching tends to be fiscally responsible. On private lands ranching is far preferable to the "highest and best" alternative, exurban development. Study after study has reported the same finding: property taxes from rural residential developments come nowhere near paying the costs of county governments and school districts, whereas farming and ranching allow counties and schools to remain in the black. In Montana, for example, for each dollar of property taxes from ranchettes, counties and school districts, on average, have to ante up $\$ 1.45$ to meet these costs. ${ }^{21}$ On farms and ranches, however, they show a surplus, having to produce only $\$ 0.25$ of goods and services for every dollar of property taxes.

What about subsidized grazing on our nation's public lands? Ranchers are accused of feeding at the public trough. ${ }^{22}$ Wait a minute, what land use is not subsidized on our public lands? Indeed, outdoor recreation, our "highest and best use" is the most heavily supported public-land use with our tax dollars. This is appropriate, considering that all of us, ranchers included, recreate on public lands.

Importantly, however, the American public benefits from allowing ranchers to graze on America's public lands. It is estimated that the 21,000 ranch families that use approximately 30,000 grazing permits on BLM and USFS lands, own about 107 million acres of private land. ${ }^{23}$ Let me ask a question and you provide your own answer to this publicprivate policy issue. In your estimation, is it a fair bargain if over 100 million acres of ecologically-rich Western private lands are kept open and productive (the private half of the bargain), knowing that approximately $85 \%$ of federal lands are being grazed at some time of the year (the public half)? I am not sure how much the public values ranching, but, perhaps if they knew that by keeping private ranchlands out of development they are helping keep the West open and out of exurban development.

Another societal benefit from this public-private partnership between ranchers and our federal land agencies is the buffering effect of the private lands. Since our region is characterized by its blend of private and public lands, the spatial context of private ranchlands might be an indicator of their regional conservation value. In the Southern Rocky Mountain Ecoregion we evaluated this by comparing the relative proportion of the landscape comprised of private ranchlands between all private land in the study area with that component of the private land within $1 \mathrm{~km}$ of publicland grazing allotments. ${ }^{8}$ The privately owned grazing lands represent $21 \%$ of all private lands in this ecoregion. But if we just look at the private lands within $1 \mathrm{~km}$ of the public land grazing allotments, the proportion of private grazing lands increases to $43 \%$. This observation supports the notion that private ranchlands provide a land-use buffer around our public lands.

\section{Culture}

The West is a region of diverse ecosystems, cultures, and economies. Ranching as a land use, and ranchers as a culture have been with us for over 400 years, dating back to the early Spanish colonists who struggled northward over El Paso del Norte and found a home for their livestock near present-day Espanola, New Mexico. If what I have presented in this essay is true, that ranchers and ranching are disproportionately important to the ecology, economy, and culture of a West that works, then why are ranchers and ranching vilified? Consider this quote by a learned academic at a Western university:

The primary environmental objection to expanded residential activity is that subdivisions and urbanization damage the landscape in a variety of ways. But that is rarely an alternative use to which the land would be put. The appropriate comparison is between the environmental impact of ranching activity and that of residential use. We must put our agrarian sympathies aside: ranching does not step lightly on the land. ${ }^{24}$

Or this by Kieran Suckling of the Center for Biological Diversity:

Yes, we are destroying a way of life that goes back 100 years. But it's a way of life that is one of the most destructive in our county... Ranching is one of the most nibilistic life styles that the planet has ever seen. It should end. Good riddance. ${ }^{25}$ 
What does one say to such final pronouncements of cultural continuation? If ranching is to flourish, persist, or disappear in the West, it should be a conscious decision, based on informed discussions, not due to apathy or neglect. Or hate.

Perhaps these inflammatory statements are reflections of nothing more than different values. Might some Westerners want the public and private lands free of manure, cows, sheep, and fences because they want them for their own uses, such as mountain biking and river rafting? Do some want ranchers and their livestock off the Western ranges because they believe what others have told them-that cows and sheep sandblast land and that cattle barons are arrogant and intolerant of any but their own kind? Perhaps Americans are content to import their food from distant lands rather than have a more intimate association with the origin of their food.

My own sense is that differing values and distorted mythology can obscure facts, and that at the end of the day, emotion may trump judgment. Would it make any difference if we found that ranchers are stewards of the land; that cows are being used as a tool in the recovery of arid ecosystems; or that open space, biodiversity, and county coffers are enriched more from ranching than from the rapidly eclipsing alternative, ranchettes? Perhaps.

There are those who say the only difference between ranchers and realtors is a rancher is someone who hasn't sold his ranch yet. Do ranchers care for the land, or are they developers in sheep's clothing? Certainly there are quite a few that see their ranch as their last cash crop, their private $401 \mathrm{~K}$ account. On the other hand, mounting evidence suggests that ranchers care for the West's geography every bit as much as those of us in the cities and suburbs. In Colorado the state cattlemen's association has formed a land trust. To date, 150 conservation easements, totaling over 250,000 acres, have been entrusted to it from ranch families. Indeed, in Colorado, the cattlemen's land trust is second only to The Nature Conservancy in acres protected under conservation easements. Considering the economies associated with Western ranching, it is evident that today's ranchers are in it for its lifestyle attributes, far more so than as a way to reap great profits.

Western ranching has spanned the time scale from the First Americans to the astronauts, avoiding the moving-on mandate of the get-rich-quick industries of mining and logging. Charles Wilkinson, among the most distinguished of our region's scholars, had this to say about the region's ranchers and farmers:

Yet these industries are the foundation for local economies and provide food for the nation and the world. They preserve open space. As a culture, the people of the ranches and farms have settled in so deeply and for so long that for all practical purposes they are indigenous societies. ${ }^{26}$
In the heated arguments between ranchers and environmentalists, I will admit to coming down on the rancher's side. In our New West that is increasingly dominated by urban, suburban, and recently exurban Westerners, it occurs to me that perhaps we could settle the New West better than we conquered the Old West if we listened to the cultures that had been here before us (and that endure still). Might we have made a better place of this region if we had slowed down enough to listen to the First Americans? Did they have something to teach us about the region's wildlife, rivers and streams, grass and forests? In the words of Wendell Berry, "As important a reason as any to support ranching, farming, irrigating, and logging is that our society will need them as teachers, mentors, and critics in the years to come." ${ }^{27}$

So today, in our haste to remake ourselves once more into the Next West, might we avoid some mistakes if we showed respect to the ranching culture? A definitive answer to that question eludes me but my gut says yes, going slow and getting to know one's human and natural histories is essential to living well on a place.

\section{Conclusion}

Do ranchers, the noun, and ranching, the verb, qualify as keystone species based on their ecological, economic, and cultural importance? Ranch families working viable ranches that sustain ecosystem services and contribute to the social fabric and local economies are critical to a West that works. Ranchers, in addition to their other vital services, are an essential component to an intact rather than a subdivided West. Whether the land that is now in ranching remains in ranching or shifts to other uses, we are up against the same need: to keep this land unfragmented.

America is gradually waking up to one consequence of our globalizing economy; the loss of locally produced food on private lands that provide critical ecosystem services and open space. As ranching diminishes in the West and agricultural jobs move offshore, so too does the opportunity for our urban publics to reconnect with the rural tasks of husbanding food on well-stewarded land. ${ }^{1}$

Interestingly, these fragile relationships even relate to homeland security. When viewed in the light of rural and urban America, our government's concern over "Homeland Security" misses the most important point. A secure homeland is not simply based on military might. Home, land, and security blend together when urban people realize that ecologically sustainable food production is possible and that rural cultures matter, and when urban people are prepared to compensate farmers and ranchers for a healthy food product as well as for protecting open space, wildlife habitat, and watersheds. Gary Nabhan captured this when he wrote:

The simplest fact about Western ranches is the one most folks tend to forget: raising range-fed livestock is one of the few economic activities that produces food — and potentially 
ecosystem health and financial wealth-by keeping

landscapes relatively wild, diverse, and resilient. ${ }^{28}$

Imagine a time when Westerners eat locally produced food from private and public open spaces, offered and received with grace and a fair market value by urban people who no longer take for granted the societal services of local farmers and ranchers. Equally important to this winning equation are rural people who acknowledge the importance of urban areas and offer a friendly handshake to their urban neighbors. Perhaps to envision this, we need to remind ourselves that humans, whether rural or urban, can be keystone species or the ultimate weedy species, depending on their relationships to the land.

\section{Acknowledgments}

I thank Jim Thorpe, rancher, English major, and active participant in a West-that-works for his encouragement. Members and supporters of the Quivira Coalition (quiviracoalition.org) and the Malpai Borderlands Group (www. malpaiborderlandsgroup.org) have my deepest gratitude for making the "radical center" a safe harbor for those who emphasize communitarian rather than contrarian tendencies.

\section{References}

1. Knight, R. L. 2007. Bridging the great divide: reconnecting rural and urban communities in the New West. In L. Pritchett, R. L. Knight, and J. Lee [EDs.]. Home land: ranching and a West that works. Boulder, CO: Johnson Books. p. 13-25.

2. Riebsame, W. E. [ed.]. 1997. Atlas of the New West: Portrait of a changing region. New York, NY: W. W. Norton \& Co. $192 \mathrm{p}$.

3. Baron, J. S. [ED.]. 2002. Rocky Mountain futures: An ecological perspective. Washington, DC: Island Press. 325 p.

4. Garnsey, M. E. 1950. America's new frontier: The Mountain West. New York, NY: Alfred A. Knopf. 314 p.

5. Morgan, N. 1961. Westward tilt: The American West today. New York, NY: Random House. 411 p.

6. Knight, R. L., W. C. Gilgert, and E. Marston [eds.]. 2002. Ranching west of the 100th meridian: Culture, ecology, and economics. Washington, DC: Island Press. 259 p.

7. Sсотt, J. M., R. J. F. Аввiтt, and C. R. Groves. 2000. What are we protecting? The United States conservation portfolio. Conservation Biology in Practice 2:18-19.

8. Talbert, C. B., R. L. Knight, and J. F. Mitchell. 2007. Private ranchlands and public-land grazing in the Southern Rocky Mountains. Rangelands 29:5-8.

9. Losos, E., J. Hayes, A. Phillips, D. Wilcove, And C. Alkire. 1995. Taxpayer-subsidized resource extraction harms species. BioScience 45:446-455.

10. Czech, B., P. R. Krausman, and P. K. Devers. 2000. Economic associations among causes of species endangerment in the United States. BioScience 50:593-601.

11. Knight, R. L., And K. J. Gutzwiller [eds.]. 1995. Wildlife and recreationists: Coexistence through management and research. Washington, DC: Island Press. 372 p.
12. Mitchell, J. F., R. L. Knight, and R. J. Camp. 2002. Landscape attributes of subdivided ranches. Rangelands 24: 3-9.

13. Maestas, J. D., R. L. Knight, and W. C. Gilgert. 2003. Biodiversity across a rural land-use gradient. Conservation Biology 15:1143-1150.

14. Maestas, J. D., R. L. Knight, and W. C. Gilgert. 2002. Cows, condos, or neither: what's best for rangeland ecosystems? Rangelands 24:36-42.

15. Leopold, A. 1933. Game management. New York, NY: Charles Scribner's Sons. 481 p.

16. Hansen, A. J., R. Rasker, B. Maxwell, J. J. Rotella, J. D. Johnson, A. Wright Parmenter, U. Langner, W. B. Cohen, R. L. Lawrence, and M. R. V. Kraska. 2002. Ecological causes and consequences of demographic change in the New West. BioScience 52:151-162.

17. Hansen, A. J., R. L. Knight, J. Marzluff, S. Powell, K. Brown, P. H. Gude, and K. Jones. 2005. Effect of exurban development on biodiversity: patterns, mechanisms, and research needs. Ecological Applications 15:151-168.

18. Donahue, D. 1999. The Western Range revisited: Removing livestock from public lands to conserve nation biodiversity. Norman, OK: University of Oklahoma Press. 352 p.

19. Stohlgren, T 1999. How grazing and soil quality affect native and exotic plant diversity in Rocky Mountain grasslands. Ecological Applications 9:45-64.

20. Sayre, N. F. 2001. The new ranch handbook: A guide to restoring Western rangelands. Santa Fe, NM: The Quivira Coalition. 102 p.

21. Haggerty, M. 1996. Fiscal impact of different land uses on county government and school districts in Gallatin County, Montana. Bozeman, MT: Local Government Center, Montana State University. $42 \mathrm{p}$.

22. Wuerthner, G., and M. Matteson. 2002. Welfare ranching: The subsidized destruction of the American West. San Francisco, CA: Foundations for Deep Ecology. 368 p.

23. Gentner, B. J., and J. A. Tanaka. 2002. Classifying federal public land grazing permittees. Journal of Range Management 55:2-11.

24. Power, T. M. 1996. Lost landscapes and failed economies: The search for a value of place. Washington, DC: Island Press. 304 p.

25. Suckling, K. 1998. The Washington Post, February 1, p 55.

26. Wilkinson, C. 1989. The American West: A narrative bibliography and a study in regionalism. Niwot, CO: University Press of Colorado. $144 \mathrm{p}$.

27. Annual meeting of the Quivira Coalition, 2007, Albuquerque, NM.

28. Nabban, G. P. 2006. In praise, and in appraisal of, the working landscapes of the West. Quivira Coalition Journal 29:11-13.

Author is a professor of wildlife conservation in the Department of Forest, Rangeland, and Watershed Sterwardship, Colorado State University, Fort Collins, CO 80523, knight@cnr.colostate. edu. 